Brit. F. vener. Dis. (1967), 43, 48.

\title{
IMMUNOLOGICAL AND EPIDEMIOLOGICAL INVESTIGATIONS OF GENITAL STRAINS OF HERPES SIMPLEX VIRUS*†
}

\author{
BY \\ DAVID C. HUTFIELD (1) \\ St. Thomas' Hospital, London \\ AND \\ G. D. WASLEY (2) AND ESTHER GRAY (3) \\ Wright-Fleming Institute of Microbiology, St. Mary's Hospital Medical School, London
}

Recent investigations have indicated that strains of herpes simplex virus isolated from the lesions of herpes genitalis may possess certain properties differentiating them from strains causing the disease in other parts of the body (Barton, 1965); the pocks produced when genital strains are freshly isolated on the chorio-allantoic membrane of the embryonated hen's egg are larger than those of nongenital strains. Munk and Donner (1963) also found differences in plaque size and cytopathic effects when these strains were inoculated into tissue cultures. There is, however, probably only a single immunological type of herpes simplex virus, although different strains may show small differences in cross complement-fixation and neutralization reactions (Plummer, 1964). We have carried out serological investigations on a cross-section of patients attending the venereal diseases department, using a genital strain of herpes simplex virus as an antigen in neutralization tests and a non-specific herpes simplex antigen in complement-fixation tests, with results that have shown a considerable variation in the number of patients possessing herpes simplex antibodies and for which we have tried to offer suitable explanations.

Subclinical carriage of herpes simplex virus in the mouths of healthy adults has been estimated to be between 1 and 2 per cent. (Buddingh, Schrum, Lanier, and Guidry, 1953; Stern, Elek, Millar, and

* Part of a thesis for the degree of M.D. of the University of London.

(1) Present address: Dept. of Venereal Diseases, The Royal Infirmary, Manchester.

(2) Present address : Dept. of Medical Microbiology, St. Thomas'

(2) Present address: Dept. of Medical M

(3) Present address: Beecham Research Laboratories, Brookham Park, Betchworth, Surrey.

† Received for publication June 6, 1966.
Anderson, 1959). However, there has been no previous investigation of the incidence of subclinical carriage of genital strains of herpes simplex virus in females. We have investigated the genital tracts of a cross-section of female patients attending the venereal diseases department by means of tissue culture inoculations, with results that have given further information concerning the epidemiology of this disease.

(I) Investigations of Antibody Status of a Sample Population attending the Venereal Patients and Methods Diseases Department

The series consisted of 100 patients attending the venereal diseases department. The average age was $27 \cdot 4$ years (range 18 to 54 ); 86 were male and fourteen were female; forty were coloured and sixty were white. The white patients included 44 from the United Kingdom, of whom 39 were from London.

A history of previous herpetic infection was obtained from 37 patients; 33 gave a history of recurrent "cold" sores of the lips, and four of recurrent genital herpes. One female patient had been a contact of a male suffering from an attack of genital herpes.

\section{Complement-Fixation Tests}

The technique was that described by Bradstreet and Taylor (1962). Blood samples were collected in glass tubes and allowed to clot. The serum was separated by centrifugation and stored at $-20^{\circ} \mathrm{C}$. so as to prevent its becoming anticomplementary. Herpes simplex antigen and positive control antiserum were reconstituted from freeze-dried material 
supplied by the Standards Laboratory, Colindale. The source of complement was guinea-pig serum preserved by the method of Richardson (1941) and supplied by Burroughs Wellcome \& Co., from whom sheep red cells preserved in Alsever's solution were also obtained. Buffered diluent containing calcium and magnesium ions (Fulton and Dumbell, 1949) was used throughout the experiment to maintain an optimum $\mathrm{pH}$ of $6 \cdot 8$ to $7 \cdot 4$.

Standardization tests were performed by means of a "chess-board" titration to determine the optimal sensitizing concentration of haemolytic serum and the titre of complement to be used in subsequent tests. The optimal concentration of herpes simplex antigen and the titre of positive control antiserum were also determined by means of a "chess-board" titration. With the completion of standardization tests, complement-fixation tests were performed on the 100 serum specimens using a 1 in 5 dilution.

\section{Neutralization Tests}

For this study a genital strain of herpes simplex virus was supplied by the Virus Reference Laboratory at Colindale. The virus had previously been grown on the chorio-allantoic membrane of the developing chick embryo. A ground suspension of the membrane was prepared. It was then centrifuged at 2,000 r.p.m. and 50 per cent. glycerol was added to the supernatant. This constituted the stock virus which was stored at $-20^{\circ} \mathrm{C}$.

Before use, all sera were inactivated at $55^{\circ} \mathrm{C}$. for 20 minutes and dilutions of 1 in 5 and 1 in 50 were prepared. These were mixed with an equal quantity of the appropriate virus dilution previously titrated so as to contain 100 to 200 plaque-forming doses in $0.1 \mathrm{ml}$. The mixture was allowed to react for an hour at $37^{\circ} \mathrm{C} \cdot 0 \cdot 2 \mathrm{ml}$. quantities were then added to tube cultures of chick embryo fibroblasts. The tubes were incubated at $35^{\circ} \mathrm{C}$. for 2 days before being examined, at which time control tubes containing either virus alone or virus with negative serum showed 100 to 200 plaques of cytopathic effect. Control tubes containing virus and positive serum which produced no growth after 2 days were also set up.

After incubation for 2 days, counts of the lesions in the culture tubes under test were made and the results expressed as a percentage neutralization of control counts with known negative serum. Neutralization greater than 50 per cent. which occurred in a dilution greater than 1 in 10 was recorded as a positive result, whereas a reduction of 50 per cent. or less of the control count was recorded as a negative result.
(2) Investigation of Incidence of Subclinical Recurrences in Female Genital Tracts

\section{Patients and Methods}

The series consisted of 100 female patients attending the venereal diseases department. The average age was $26 \cdot 3$ years (range 15 to 60 ); 37 were coloured and 63 were white. The white patients included 55 from the United Kingdom.

A history of previous herpetic infection was obtained from 35 patients; 25 of these had suffered from recurrent "cold" sores of the lips, one having been a contact 7 days previously of a male who had an attack of genital herpes and also suffered from recurrent "cold" sores of the lips. Ten other patients had recovered from attacks of genital herpes up to 6 days and 10 weeks previously.

Specimens for virus investigation were obtained at the time of menstruation from five patients, within 7 days of the last menstrual period from eighteen patients, between 7 and 14 days since the last menstrual period from 23 patients, and between 14 and 28 days since the last menstrual period or within 14 days of the expected onset of menstruation from nineteen patients. Specimens were obtained from nine pregnant patients, five in the first trimester, three in the second, and one in the third. Specimens were also obtained from two patients who were post-menopausal.

The specimens from 28 patients were alkaline in reaction, those from 53 patients were acid, and those from nineteen patients were neutral.

\section{Tissue Culture Techniques}

The genital tracts of 100 female patients with venereal diseases were investigated for the presence of herpes simplex virus particles by means of tissue culture. In each case superficial scrapings containing epithelial cells and glandular secretions were obtained from the cervix, cervical canal, posterior vaginal fornix, lateral vaginal walls, and introitus with a sterile platinum loop. This material was immediately transferred into carefully-labelled specimen bottles containing Hanks's fluid in which were $100 \mathrm{units} / \mathrm{ml}$. penicillin, $100 \mu \mathrm{g} . / \mathrm{ml}$. streptomycin, $2.5 \mu \mathrm{g} . / \mathrm{ml}$. fungazone, and phenolphthalein as an indicator. The specimens were then stored in a "deep freeze" at $-20^{\circ} \mathrm{C}$.

Before use the specimens were thawed and, by means of a graduated pipette, $0.1 \mathrm{ml}$. was transferred to each of the two tubes containing HeLa cells in $1 \mathrm{ml}$. Eagle's medium with 2 per cent. calf serum. A corresponding set of control tubes containing HeLa cells and growth medium only was also set up at the same time. Incubation was 
then continued at $35^{\circ} \mathrm{C}$. with the tubes in a stationary position. Examination by means of phasecontrast microscopy so as to observe cellular changes associated with herpes simplex virus growth was then performed daily for the next 10 days, after which the specimens were discarded. Similar observations were also carried out with tubes of $\mathrm{Hep}_{2}$ cells that were incubated on rollers at $37^{\circ} \mathrm{C}$.

\section{Results}

The number and percentage of patients that possessed herpes simplex complement-fixation antibodies is shown in Table $I$.

TABLE I

INCIDENCE OF COMPLEMENT-FIXING ANTIBODIES TO HERPES SIMPLEX IN 100 PATIENTS

\begin{tabular}{l|c|c|c}
\hline Classification & $\begin{array}{c}\text { No. of } \\
\text { Patients } \\
\text { Investigated }\end{array}$ & \begin{tabular}{c} 
Complement-fixing Antibodies \\
\cline { 2 - 3 } $\begin{array}{l}\text { Total Male and } \\
\text { Female }\end{array}$
\end{tabular} & $\begin{array}{c}\text { No. } \\
\text { Per cent. }\end{array}$ \\
\hline White & 60 & 49 & 49 \\
\hline Coloured & 40 & 26 & $43 \cdot 3$ \\
\hline London Origin & 39 & 23 & $57 \cdot 5$ \\
\hline Female & 15 & 17 & $43 \cdot 5$ \\
\hline
\end{tabular}

The number and percentage of patients that possessed neutralizing antibodies to a genital strain of herpes simplex virus is shown in Table II.

TABLE II

INCIDENCE OF NEUTRALIZING ANTIBODIES TO HERPES SIMPLEX IN 100 PATIENTS

\begin{tabular}{|c|c|c|c|}
\hline \multirow{2}{*}{ Classification } & \multirow{2}{*}{$\begin{array}{c}\text { No. of } \\
\text { Patients } \\
\text { Investigated }\end{array}$} & \multicolumn{2}{|c|}{ Neutralizing Antibodies } \\
\hline & & No. & Per cent. \\
\hline $\begin{array}{l}\text { Total Male and } \\
\text { Female }\end{array}$ & 100 & 81 & 81 \\
\hline White & 60 & 50 & $83 \cdot 4$ \\
\hline Coloured & 40 & 31 & $77 \cdot 5$ \\
\hline London Origin & 39 & 31 & $79 \cdot 5$ \\
\hline Female & 15 & 13 & $86 \cdot 7$ \\
\hline
\end{tabular}

In 81 cases the neutralization test was positive at a serum dilution of 1 in 10; in 37 at 1 in 100; and in two at 1 in 1,000 .

Tissue Culture Inoculation Tests No herpes simplex viruses were isolated from the genital tracts of any of the 100 female patients investigated in this experiment.

\section{Discussion}

49 per cent. of the patients investigated possessed complement-fixing antibodies and 81 per cent. neutralizing antibodies. This marked difference in the incidence of complement-fixing and neutralizing antibodies is somewhat at variance with the findings of other workers who have demonstrated that in adults these antibodies almost always co-exist (Hayward, 1950; Gajdusek, Robbins, and Robbins, 1952; Holzel, Feldman, Tobin, and Harper, 1953; Dascomb, Adair, and Rogers, 1955) and usually have comparable titres (Sosa-Martinez and Lennette, 1955; Schmidt and Lennette, 1961). These authors showed that complement-fixing antibodies rarely occur without neutralizing antibodies, although the latter may occasionally occur alone, particularly as a result of mild primary illness. One explanation of the present findings is a low sensitivity of the complement-fixation test used; complement-fixing antibody titres are normally slightly less than neutralizing antibody titres and might be just below detectable levels. Thus Balducci, Tyrrell, and Stuart-Harris (1956) showed that a proportion of apparently negative complement-fixing reactors depends on the potency of the complement-fixing antigen used.

A second possible explanation is the existence of a number of serological strains of herpes simplex virus, in particular specific genital strains. Since a genital strain was used in the neutralization tests but not in the complement-fixation tests, this could account for the difference. Indeed, on the basis of neutralization tests, two cross-reacting subtypes of herpes simplex have been recognized (Plummer, 1964). There is some evidence that genital strains are biologically different from other strains, on the basis of pock size on chorioallantoic membrane (Barton, 1965); however, no evidence has yet been recorded as to serological differences. Such minor differences in serological reactivity could account for the different sensitivities of the two tests used here. Possible evidence in support of this may be found in that three patients who suffered from recurrent attacks of herpes genitalis had negative complement-fixation tests but positive neutralization tests. In another patient, however, who suffered from the recurrent syndrome, both types of antibody were present. A female contact of a male suffering from genital herpes was also found to have a negative complement-fixation test but a positive neutralization test, although no genital lesions were present. 
An antibody incidence of 81 per cent. agrees with the findings of Holzel and others (1953) in Great Britain and with those of Buddingh and others (1953) and Scott, Coriell, Blank, and Burgoon (1952) in the United States of America. The incidence varies with the socio-economic status of the population tested. In groups with high living standards, adult incidence may be as low as 40 to 50 per cent. (Stern and others, 1959). The present figure of 81 per cent. is thus compatible with the probable socio-economic status of the group surveyed here. There was, however, a difference of only 5.9 per cent. between the white and coloured groups, the white possessing 83.4 and the coloured 77.5 per cent. White patients of London origin possessed $79 \cdot 5$ per cent.

It would appear that 81 per cent. of patients seen in the venereal diseases department would constitute the reservoir of recurrent herpetic cases, whereas only nineteen per cent. are prone to primary infection. These figures, therefore, support clinical findings that the majority of cases of herpes genitalis seen in the venereal diseases department are probably recurrent attacks. This cannot be stated definitely, however, since the incidence of recurrent attacks in patients with past primary infection is not known. Only about 10 per cent. of persons with antibodies suffer with recurrent "cold" sores and the incidence of recurrences in genital herpes is unknown. In a survey of 140 cases of herpes genitalis, however, $39 \cdot 3$ per cent., as determined by history and subsequent observation, were prone to recurrences. In the remainder it was not known how many were primary or recurrent infections, since no history of previous attacks could be obtained from those who had suffered a primary infection in early childhood, or had had a previous subclinical infection.

It would appear from the results of tissue culture inoculations that females do not act as vaginal carriers of herpes simplex virus in the absence of genital herpetic lesions, and that the incidence of symptomless excretion of herpes virus in female genital tracts is very low or less than 1 per cent. It is possible that the virus is unable to survive the acid vaginal secretions caused by the fermentation reactions of Döderlein's bacillus, since infectivity is rapidly lost at a $\mathrm{pH}$ of less than 7, particularly at a $\mathrm{pH}$ level of 3 . In the 100 specimens collected in this experiment, 53 gave a reaction to an indicator within this range. In contrast the human mouth has been shown to act as a carrier, and it would appear that saliva is a more favourable medium for survival of the virus. The incidence of subclinical carriage of herpes virus in the mouths of healthy adults is only 1 or 2 per cent. (Buddingh and others, 1953; Stern and others, 1959). Since oral infection with herpes virus is considerably more common in the population than genital tract infection, a carrier incidence in the genital tract of less than 1 per cent. would be expected.

It would seem that primary venereal attacks of genital herpes in the male are more likely to be acquired from infective herpetic lesions on the female genitalia rather than from women with symptomless and subclinical excretion of virus. Primary venereal attacks in the male are, therefore, more likely to be associated with a simultaneous eruption in the female which, as a result of contact tracing, was seen in less than 1 per cent. in a survey of 140 cases. It is possible, therefore, that the majority of cases of genital herpes seen in the venereal diseases department are recurrent attacks mainly associated with the trauma of intercourse, since ten male cases are seen to every female case.

It appears unlikely that neonatal herpes simplex infection can be acquired as a result of contamination with latent virus in the birth canal. In those infants who develop neonatal herpes in the absence of genital lesions in the mother, it is possible that cross-infection in the maternity ward is an important factor. A midwife or nurse who is a salivary carrier or infected with an herpetic stomatitis or whitlow is a likely source of infection. Another source of infection may be a mother with a primary herpetic stomatitis who can infect a newborn child by kissing. Measures to combat cross-infection in maternity wards should, therefore, be rigorous for herpes simplex infections, since the consequences to newborn and in particular to premature infants can be lethal.

\section{Summary}

One hundred patients attending a venereal diseases clinic were investigated for the presence of herpes simplex antibodies. Complement-fixation antibodies against a non-specific herpes simplex antigen were present in 49 per cent. and neutralizing antibodies against a genital strain of herpes simplex virus in 81 per cent. of those attending. This marked difference in incidence may be due to the potency of the complement-fixation antigen used or to the possible existence of a number of serological strains of herpes simplex viruses, in particular specific genital strains.

The genital tracts of 100 female patients attending a venereal diseases clinic were investigated by tissue culture inoculations for the presence of subclinical 
recurrences, but no herpes simplex viruses were isolated. It is possible that the virus may not be able to survive acid vaginal secretions caused by the fermentation reactions of Döderlein's bacillus, since infectivity is rapidly lost in acid media.

We are grateful to Dr C. S. Nicol, M.D., F.R.C.P., consultant venereologist, St. Thomas' Hospital, for permitting us to use his patients in this study; and to Prof. K. Dumbell, M.D., Department of Virology, The Wright-Fleming Institute of Microbiology, St. Mary's Hospital Medical School; Prof. A. P. Waterson, M.D., M.R.C.P., Department of Medical Microbiology, St. Thomas' Hospital Medical School; and Dr H. Stern, M.B., Ch.B., Ph.D., M.C. Path., Reader in Virology, St. George's Hospital Medical School, for their encouragement and support for this work.

\section{REFERENCES}

Balducci, D., Tyrrell, D. A. J., and Stuart-Harris, C. H. (1956). Arch. ges. Virusforsch., 7, 28.

Barton, B. W. (1965). Public Health Laboratory Service, Colindale, personal communication.

Bradstreet, C. M. P., and Taylor, C. E. D. (1962). Monthly Bull. Minist. Hlth, 21, 96.

Buddingh, G. J., Schrum, D. I., Lanier, J. C., and Guidry, D. J. (1953). Pediatrics, 11, 595.

Dascomb, H. E., Adair, C. V., and Rogers, N. (1955). f. Lab. clin. Med., 46, 1.

Fulton, F., and Dumbell, K. R. (1949).F. gen. Microbiol., 3, 97.

Gajdusek, D. L., Robbins, M. L., and Robbins, F. C. (1952). F. Amer. med. Ass., 149, 235.

Hayward, M. E. (1950). Lancet, 1, 856.

Holzel, A., Feldman, G. V., Tobin, J. O'H., and Harper, J. (1953). Acta paediat. (Uppsala), 42, 206.

Munk, K., and Donner, D. (1963). Arch. ges. Virusforsch., 13, 529.
Plummer, G. (1964). Brit. F. exp. Path., 45, 135.

Richardson, G. M. (1941). Lancet, 2, 696.

Scott, T. F. M., Coriell, L., Blank, H., and Burgoon, C. F. (1952). F. Pediat., 41, 835.

Schmidt, N. J., and Lennette, E. H. (1961). F. Immunol., 86, 137.

Sosa-Martinez, J., and Lennette, E. H. (1955). F. Bact., 70, 205.

Stern, H., Elek, S. D., Millar, D. M., and Anderson, H. F. (1959). Lancet, 2, 871.

Les recherches immunologiques et épidémiologiques à propos des souches génitales du virus herpes simplex

\section{RÉSUMÉ}

Cent malades visitant un dispensaire anti-vénérien ont été examinés pour la présence d'anticorps du virus herpes simplex. Des anticorps contre un antigène non-spécifique du virus herpes simplex ont été révélés par le test de fixation du complément dans 49 pour cent des cas et des anticorps neutralisants contre une souche génitale du virus simplex chez 81 pour cent des malades visitant ce dispensaire. Cette différence marquée dans l'incidence peut être due à l'éfficacité de l'antigène utilisé pour le test de fixation du complément ou a l'existence possible d'un nombre de souches sériques des virus de l'herpes simplex dans certaines souches génitales spécifiques.

Les voies génitales de 100 patients visitant un dispensaire anti-vénérien ont été examinées en faisant un ensemencement à un milieu de culture de tissus afin de révéler la présence des rechutes sous-cliniques, mais aucun virus de l'herpes simplex n'a été isolé. Il est possible que le virus ne puisse pas survivre aux sécrétions vaginales acides formées par la fermentation du bacille de Döderlein du fait que le germe de l'infection est détruit rapidement dans les milieux acides. 